\title{
Prospects and Paths of CICA's Transformation
}

Chen Dongxiao

\begin{abstract}
The Conference on Interaction and Confidence Building Measures in Asia (CICA) is at a critical juncture of development and transformation. In the past two decades, CICA has developed itself into the most representative and inclusive pan-Asian forum on regional security and cooperation, making steady progress on confidence building and regional cooperation, as well as promoting ideas of comprehensive, common, cooperative, and sustainable security. CICA has played a unique role in gradually raising Asia's self-awareness on a regional security agenda and regional architecture building. Nevertheless, CICA's overall influence on Asia's security agenda is still limited, its potential is far from being fully realized, let alone its long-term goal of upgrading into an organization of security and cooperation in asia (OSCA). In the context of changing dynamics in the regional security landscape, there are both great opportunities and huge challenges for CICA's further development and transformation. China, as the chairing country of CICA in the next few years, should show its stewardship to strategically prioritize CICA's road map for its transformation, by enhancing CICA's capacity and institutional building, improving the efficacy of CBMs for
\end{abstract}

Chen Dongxiao is President of Shanghai Institutes for International Studies (SIIS) and Editor-in-Chief of the China Quarterly of International Strategic Studies (CQISS). The author would like to thank Dr. Feng Shuai of SIIS for his committed assistance during the writing of this article.

(c) 2015 World Century Publishing Corporation and Shanghai Institutes for International Studies China Quarterly of International Strategic Studies, Vol. 1, No. 3, 447-469

DOI: $10.1142 / S 2377740015500232$ 
regional security, and helping build CICA's capability of delivering more regional security public goods. For the purpose of realizing these agendas of CICA, China should not only work more closely with the core members of CICA, but also engage well with extra-regional powers, particularly the United States, in the area of regional security architecture building.

Keywords: CICA; regional security architecture; Asian security concept; confidence building measures; win-win cooperation.

The Conference on Interaction and Confidence Building Measures in Asia (CICA) is an international forum intended to ensure Asia's peace, security, and stability by strengthening regional cooperation. ${ }^{1}$ Established in 1992 according to the proposal of President Nazarbayev of Kazakhstan, CICA has been taking the Organization on Security and Cooperation in Asia (OSCA) as its goal of future development. Given the increasingly complicated security environment in Asia, the course of CICA's transformation and development has been both imperative and challenging. What are the aspects necessary for CICA to develop into OSCA? How possible is such a transformation? What difficulties and challenges does it face? How should members of CICA work together to create conditions for its successful transformation? These are the main themes to be addressed in the article.

\section{Necessity of CICA's Transformation}

As of 2014, CICA had developed into a multilateral international platform boasting 26 member states and 11 observers (states or international organizations), completed the formulation of basic documents with respect to mission, vision, and operational principle and structure, and established such mechanisms as a leaders' summit and the meeting of

\footnotetext{
${ }^{1}$ For a more detailed depiction of CICA's function, see the Declaration on the Principles Guiding Relations between the CICA Member States, signed at the meeting of CICA ministers of foreign affairs on September 14, 1999, in Almaty, Kazakhstan, and Almaty Act, the charter of the CICA, adopted at the First Summit Meeting held in Almaty on June 4, 2002. http://www. s-cica.org/page.php?page_id=7\&lang=1.
} 
ministers of foreign affairs as well as confidence building measures (CBMs) in multiple areas. ${ }^{2}$

However, CICA's international influence is still limited, and is not up to par whether in terms of regional security capacity building or regional security risk reduction. ${ }^{3}$ Meanwhile, the security environment in the Asian region and the initial objective of CICA's transformation have posed urgent requirements, both exogenously and endogenously, for upgrading and transformation of CICA into OSCA as its inevitable trajectory.

CICA must

transform into a more inclusive and forceful regional security platform due to the changing security dynamics of Asia.

The daunting and complicated situation of Asia's security is calling for the emergence of a regional security institution featuring both representativeness and inclusiveness, providing Asian countries the key role in addressing regional security as well as in the building of regional security architecture.

Since the beginning of the new century, the region has been increasingly integrated through trade, finance, production, and flows of people, money, and technology, while also undergoing a major power shift that reflects the economic dynamism, growing capability, and proactivity of emerging powers. Within the boundaries of Asia, traditional security tensions in some parts of Asia such as the Middle East, Afghanistan, and the Korean Peninsula are still heating up, while new security issues such as territorial disputes over islands in the East China Sea and South China Sea are intensifying in recent years. Meanwhile, some non-traditional security threats such as terrorism, drug trafficking, pandemic diseases, water scarcity, and food safety have kept escalating. Security dilemmas have also

\footnotetext{
${ }^{2}$ For detailed information about CICA's evolution and its main achievements, see "Evolution of CICA Process" at http://www.s-cica.org/page.php?page_id=141\&lang $=1 \&$ parent_id $=133$.

${ }^{3}$ In Asia, existing multi-layered bilateral and multilateral regional/sub-regional security mechanisms, including EAS, ARF, SAARC, SCO, Pacific Islands Forum as well as the U.S.led bilateral alliance system in the Asia-Pacific are competing for influence in various parts of Asia, thus making Asia the only continent without a macro-regional or overarching pan-regional architecture.
} 
emerged in parts of Asia to varying degrees, and the tensions from conflicts among some major countries are also on the rise. ${ }^{4}$

In terms of the existing regional security institutions, the U.S.-led huband-spokes alliance system that has survived the Cold War and maintained its dominant role in regional security, particularly in East Asia, has confronted more challenges in the face of constantly emerging new and traditional security threats. In particular, against the backdrop of the rise of emerging powers such as China and India and the occurrence of important changes in Asia's power reconfiguration, the limitations of the exclusive alliance system dominated by the United States have become increasingly prominent.

Meanwhile, there are quite obvious cognitive differences between the United States and China, as well as other major Asian countries in terms of the perception of security threats, the mode of security governance, etc. ${ }^{5}$ The less well-established, or even lack of, regional security consensus among major players in Asia and the Asia-Pacific has resulted in many widely divergent strategic plans to address Asia's future security issues, with many conflicting and inconsistent approaches. Quite a number of regional and sub-regional security institutions and arrangement overlap in

${ }^{4}$ See, for example, Robert D. Kaplan, Asia's Cauldron (New York: Random House, 2014); William T. Tow, ed., Security Politics in the Asia-Pacific: A Regional-Global Nexus?(New York: Cambridge University Press, 2009); and Michael Wills and Robert M. Hathaway, eds., New Security Challenges in Asia (Baltimore: Johns Hopkins University Press, 2013).

${ }^{5}$ For the difference of perception between China and the United States regarding the regional security order and architecture, see, for example, Henry Kissinger, World Order, Chapters 5 and 6 (New York: Penguin Press, 2014); Wang Jisi, "North, South, East and West-China is in the 'Middle': A Geostrategic Chessboard," in China International Strategy Review 2013 (Beijing: Foreign Language Press, 2013), pp. 27-51; Ji Zhiye et al., "The Pacific Ocean is Wide Enough for All," Contemporary International Relations (November/December 2014), pp. 1-19; and Ashley J. Tellis, "Seeking Alliances and Partnerships: The Long Road to Confederationism in U.S. Grand Strategy," in Ashley J. Tellis, Abraham M. Denmark, and Greg Chaffin, eds., U.S. Alliances and Partnerships at the Center of Global Power (Seattle, WA.: The National Bureau of Asian Research, 2014), pp. 3-35. For information and analysis of Japan's strategic role in Asia, see Shinzo Abe, "A New Vision from a New Japan," speech at the annual meeting of the World Economic Forum, http;//japan.kantei.go.jp/96_abe/statement/201401/22speech_e.html; T. J. Pempel, “Back to the Future? Japan's Search for a Meaningful New Role in the Emerging Regional Order," Asian Perspective, Vol. 39, No. 3 (2015), pp. 357-380. 
terms of members and fields. Many of them are lacking in effective designs for inter-institutional collaboration and cooperation, thus leading to unavoidable overlaps in functions and even competition among some existing regional and sub-regional institutions. Streamlining the regional security architecture has always been a challenge for capacity and institutional building in Asia. ${ }^{6}$

Therefore, it is always advisable for Asia to work out a more representative, inclusive regional security institution somewhat similar to the Organization for Security and Cooperation in Europe (OSCE) to coordinate the functions of various sub-regional security mechanisms through multiple modes of cooperation and dialogue, thus making the interaction of existing regional mechanisms in the field of security more accommodative and collaborative.

At the same time, becoming a more effective regional security institution similar to OSCE in Asia is also the intention and perhaps the only ultimate path of CICA if its vision is to be fully realized.

Admittedly, CICA was designed with the OSCE as the blueprint at first. Initiating Asia's "Helsinki" Agenda with CICA as the basis to finally establish the Asian version of OSCE is itself the expectation held by Kazakh President Nazarbayev on the CICA's mission. ${ }^{7}$ Therefore, since the inception of the CICA mechanism, its internal requirement on system

${ }^{6}$ For instance, in East Asia, the debate about different visions of regional architecture has never abated. There are at least three schools of thought regarding East Asia architecture building, namely, the Canberra school, the Washington school, and the Singapore school, see Tan See Seng, "Competing Visions: EAS in Regional Architecture Debate," East Asia Forum Online, November 15, 2011, http://www.eastasiaforum.org/2011/11/15/competing-visionseas-in-the-regional-architecture-debate/; Ernest Z. Bower, “East Asia Summit, the Next Step is Structure," Center for Strategic and International Studies website, November 14, 2011, http://csis.org/publication/east-asia-summit-next-step-structure; and Jusuf Wanadi, "EAS: Calling for a New East Asia Political Architecture," East Asia Forum Online,November 18, 2011, http://www.eastasiaforum.org/2011/11/18/eas-calling-for-a-new-east-asian-politicalarchitecture/.

${ }^{7}$ Kazakh President Nazarbayev, the founder of CICA outlined his vision of CICA's long-term goal in his statement at the 47th session of the UN General Assembly, October 5, 1992, that "The second stage would involve accelerating the work of CICMA, increasing the number of its members, adapting it to the framework of a Conference on Security and Cooperation in Asia (CSCA) and forming pan-Asian structures of the CSCE type." http:// www.s-cica.org/page.php?page_id=239\&lang=1\&parent_id $=788$. 
building and goal of development have been formulated along the lines of an OSCA in the real sense.

Because the OSCE model was taken as the theoretical basis, the development strategy of expanding the representativeness as much as possible was adopted in the course of founding CICA. It maximally lowered the accession threshold and encouraged various Asian countries to participate in CICA at the broadest range. This mode allowed CICA to develop into a representative pan-Asian international forum, but it also brought various existing conflicts among Asian countries into the CICA. Because of Asia's complicated security environment and the diverse and sometimes competing security concerns and interests of its member states, what they have so far achieved is basic consensus on regional security cooperation while pursing some limited and relatively lower level of confidence building measures on security issues. There is a long way to go before CICA can play a more substantial role in addressing specific security challenges in Asia. ${ }^{8}$

If CICA attempts to become an influential part of the Asian security architecture, distinct from but supplementary to the existing regional security mechanism, upgrading CICA to an OSCA-type of pan-regional mechanism is almost its only direction of development. Only after really becoming a regional security organization capable of enhancing regional security, both in terms of promoting high-level confi-

For better collaboration of regional efforts in crisis management and confidence building, it is necessary for CICA to develop into a pan-regional OSCA. dence building and reducing the security threats, can CICA's potential be brought into full play and its original goal of development be realized.

${ }^{8}$ For CICA's achievements, see "CICA: A Road to Security in Asia," http://prositeskazakhembus.homestead.com/CICA.html; for a more detailed analysis of CICA's achievements and its challenges, see Li Xin et al., CICA: Retrospect and Outlook (Chinese Version), SIIS Report, September, 2013, http://www.siis.org.cn/index.php? $\mathrm{m}=$ content\&c=index\&a= show\&catid=130\&id=7; Mu Chunsan, "What is CICA (and Why China Cares about it)?" The Diplomat, http://thediplomat.com/2014/05/what-is-cica-and-why-does-china-care-aboutit/; and Wu Zurong, "CICA: Success and Challenges," Chinausfocus.com, May 26, 2014 http://www.chinausfocus.com/foreign-policy/cica-success-and-challenge/. 
To sum up, Asia's security environment requires a stronger CICA, and CICA also needs more sound and effective institutions to maximize its role. In view of the needs of both external conditions and internal appeals, the OSCA-type of mechanism should be the direction of CICA's future development.

\section{Advantages and Potential of CICA}

Though CICA is still at the initial stage of development, relatively lagging behind in institutional building and far from being at the center of regional security architecture, it should be noted that CICA's unique attributes, formed in the course of its development, have endowed it with huge potential for it to play a unique role in solving Asia's security issues. If CICA's potential and advantages can be fully tapped to propel its transformation and development into an OSCA, the future establishment of the new Asian security architecture will benefit greatly.

First, CICA is now the only pan-Asian security forum, matchless in terms of inclusiveness and representativeness. Besides, the new idea of security cooperation, with the "new Asian security concept" as the core tally, represents the direction of future development in the field of Asian security.

In the course of many years of development, under the previous chairing states' unremitting efforts, CICA has made remarkable achievement in increasing the number of member states and augmenting their representativeness, and it has become the most inclusive security mechanism in Asia.

Because Kazakh President Nazarbayev, while establishing the CICA mechanism, hoped to build it into Asia's Helsinki Agenda, efforts were made in the course of organizing preparation and development to increase the number of member states and observer states, and augmenting the mechanism's representativeness was taken as the fundamental achievement. In the course of development, CICA basically set no threshold for member states' accession and gave little consideration to bilateral relations among member states. Instead, it made active efforts to invite all Asian countries to be member states, and actively invited countries outside the region to participate in CICA's activities as observers. At present, CICA's 26 member states span almost all Asian areas and cover almost all 
hot security issues. ${ }^{9}$ Besides, CICA accommodates multiple sets of bilateral relations involving deep conflicts over regional security issues at the same time, showing high inclusiveness. CICA is not only a pan-Asian security mechanism, but also an epitome of Asia's complicated security environment. Among all the current Asian security mechanisms, it is the most representative.

The common, comprehensive, cooperative, and sustainable security, which was synthesized as the new Asian security concept and expounded on by Chinese President Xi Jinping in 2014 in Shanghai at the Fourth CICA Summit, is a systematic and profound elaboration of Asia's security issues highlighting the principles of cooperation, openness, and inclusiveness that the CICA mechanism has adhered to for many years. ${ }^{10}$ CICA's ideas of security and cooperation with the "new Asian security concept" as the core have stressed the importance of finding regional security with others rather than against them, which have been increasingly shared by many Asian counties, including all CICA members. ${ }^{11}$ The new Asian security concept cherished by CICA would help enhance its soft power if those principles could be applied in more CICA-led actions.

Second, among CICA's member states, major countries represented by China and Russia, and core member states consisting of regional powers represented by Kazakhstan, Turkey, and Iran, are willing and able to build a security cooperation platform to meet Asian countries' needs.

${ }^{9}$ There are 26 member states in CICA, including China, Afghanistan, Azerbaijan, Egypt, India, Iran, Israel, Kazakhstan, Kyrgyzstan, Mongolia, Pakistan, Palestine, Russia, Tajikistan, Turkey, Uzbekistan, Thailand, the Republic of Korea, Jordan, United Arab Emirates, Vietnam, Iraq, Bahrain, Cambodia, Qatar and Bangladesh, and 11 observers (including sovereign states and international organizations) - Indonesia, Malaysia, the USA, Ukraine, Japan, the Philippines, Sri Lanka, and the United Nations, the OSCE, the League of Arab States and Parliamentary Assembly of the Turkic Speaking Countries (TURKPA).

${ }^{10}$ For the full text of President Xi Jinping's remarks "New Asian Security Concept For New Progress in Security Cooperation" at the Fourth CICA Summit in Shanghai on May 21, 2014, visit http://www.cica-china.org/eng/zyhyhwj_1/yxhy/yxfh/t1170132.htm.

${ }^{11}$ Chen Guoping, "yazhou anquanguan: yinling yazhou anquan hezuo xinfangxiang [Asia Security Concept: Leading the New Direction of Asia's Security Cooperation]," Qiu Shi Journal, No. 14 (2014), http://www.cica-china.org/chn/yxzk/t1171447.htm; Shen Dingli, "Asian Awareness, Asian Security," http://www.chinausfocus.com/foreign-policy/asianawareness-asian-security/. 
CICA's full member states are all Asian countries, including not only major countries in the world such as China, Russia, and India, but also a host of middle powers and regional powers capable of playing an active role in regional issues, such as Turkey, Kazakhstan, Iran, and South Korea, etc. They jointly constitute CICA's core member states.

In the past decades, most of these core member states in CICA have made remarkable achievements in national capacity building, including economic and social development, manifesting strong national strength and regional influence and political willingness of playing important roles in the field of security. ${ }^{12}$ These CICA core countries have been coordinating a host of CBMs programs in the past decade (see Table 1), demonstrating the huge potential of collective leadership in promoting the regional security

As a rapidly

maturing pan-Asian

security mechanism,

CICA has the

potential to serve as a

solid basis for

pan-regional security

cooperation. cooperation in the future.

With in-depth cooperation among Asian countries as the basis, CICA is able to tap its potential of building itself into the new platform of regional security cooperation, realizing the mechanism's transformation and development, and ultimately achieving the goal of making Asia counties assume a leadership role in Asian security.

Third, CICA itself was established with the OSCE as the template, so it is always

${ }^{12}$ Among CICA members, China, Russia, and India are members of BRICS, along with Turkey, Vietnam, Thailand and some others, representing the key groups of emerging economies in Asia. In total, CICA members' overall GDP cover one-third of global GDP, see http://news.xinhuanet.com/video/2014-05/16/c_126508701.htm; Meanwhile the middle powers of CICA, including ROK, Turkey, and Kazakhstan, have pursued even more proactive diplomatic strategy to upgrade their regional influence respectively in the advent of the new millennium. For more analysis of middle powers' strategy, see, for example, Scott Synder, "South Korean Middle Power Diplomacy and the U.S. Rebalance," The Diplomat, March 28, 2015, http://thediplomat.com/2015/03/south-korean-middle-power-diplomacyand-the-u-s-rebalance/; Kohei Imai, "Comparative Middle Powers Diplomacy: Turkey and Japan," Middle East Institute website, November 7, 2013, http://www.mei.edu/content/ comparative-middle-power-diplomacies-turkey-and-japan; and Erlan Idrissov "Kazakhstan: Central Asia's Vital Nation: TNI Editor Speaks with Kazakh Foreign Minister Erlan Idrissov," The National Interest, June 27, 2014, http://nationalinterest.org/feature/kazakhstancentral-asias-vital-nation-10763. 
Table 1. List of Coordinating and Co-Coordinating Countries for Implementing Specific Confidence Building Measures.

\begin{tabular}{llll}
\hline No. & \multicolumn{1}{c}{ Specific CBMs } & \multicolumn{1}{c}{ Coordinator } & \multicolumn{1}{c}{ Co-coordinator } \\
\hline 1 & $\begin{array}{l}\text { Development of secure and effective } \\
\text { systems of transportation } \\
\text { corridors }\end{array}$ & Azerbaijan & India \\
& $\begin{array}{l}\text { Combating illicit drugs } \\
2\end{array}$ & Iran & Afghanistan \\
3 & Disaster management & Iran & Kyrgyzstan \\
5 & Human dimension & Kazakhstan & \\
6 & Information technology & Republic of Korea & \\
7 & Energy security & Republic of Korea & \\
& $\quad$ enterprises & Russia & Thailand, Kazakhstan \\
8 & Tourism & Tajikistan & \\
9 & New challenges and threats & Turkey & Afghanistan \\
10 & Environment & Mongolia & \\
\hline
\end{tabular}

Source: Evolution of CICA Process as of July 1, $2010 .^{13}$

motivated to become an OSCA, an Asian version of OSCE. Meanwhile, CICA already has built up some institutional foundation in the past decades, laying down some fundamentals for its incremental upgrading and transformation.

After more than 20 years of development, particularly in the past decade, CICA has adopted basic legal documents governing the institution's structure and operation, established basic meeting mechanisms such as the leaders' summit and the meeting of ministers of foreign affairs, and established the CICA Secretariat as the conference's permanent administrative body (see Fig. 1). Meanwhile, CICA has established contacts and links with regional and international organizations in support of its efforts to enhance peace, security, and economic development in Asia. CICA was conferred observer status by the United Nations General Assembly at its 62nd session in 2007. In pursuance of establishing links with other organizations, CICA has signed memoranda of understanding with various regional and international organizations, including Economic Cooperation Organization (ECO), Eurasian Economic Community (EurAsEC), International Organization for Migration (IOM), Assembly of People of

\footnotetext{
${ }^{13}$ For detailed information on the list of coordinating and co-coordinating countries for implementing specific Confidence Building Measures, see CICA's official website, http:// www.s-cica.org/page.php?page_id=141\&lang=1\&parent_id=133.
} 


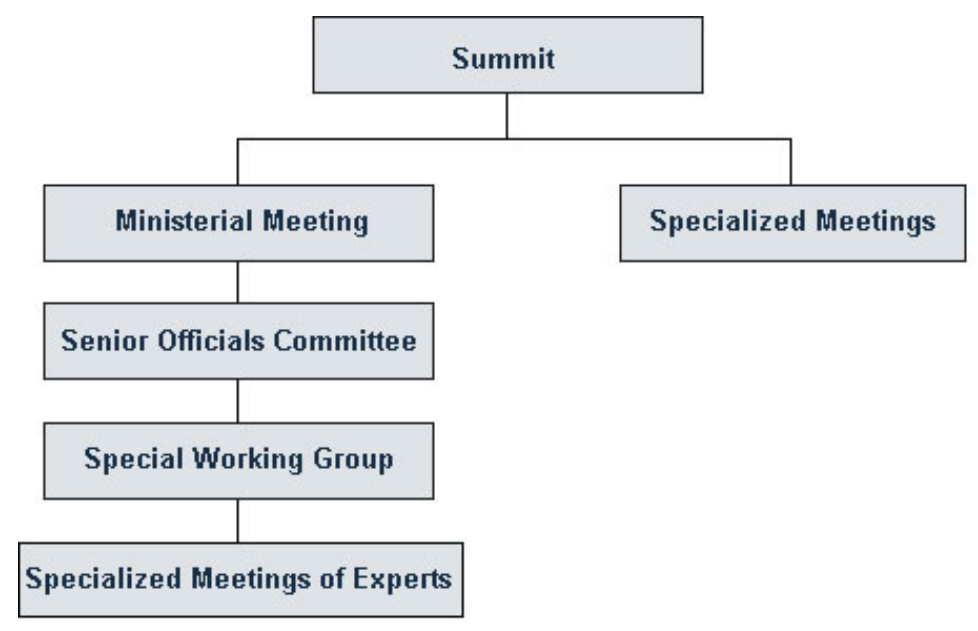

Fig. 1. CICA's Organizational Structure. Source: Official website of CICA. ${ }^{14}$

Kazakhstan (APK), Shanghai Cooperation Organization (SCO) and United Nations Office on Drugs and Crime (UNODC).

Following the Shanghai summit meeting in May 2014, CICA members have committed to intensifying their efforts of institutional building, including establishment of the CICA Youth Council, Business Council, strengthening the function of the Secretariat and upgrading the new CICA rules of procedure in order to boost more substantial CBMs and cooperation among CICA members. ${ }^{15}$ Of course, these achievements only provide a basic framework for future development, and governance mechanisms at deeper levels have yet to be further improved. Nevertheless, the current institutional buildings have already laid down an important macroscopic foundation for CICA's further upgrading and transformation.

In summary, as a security dialogue platform, CICA with its pan-Asian representativeness and inclusiveness has already achieved remarkable progress in building up Asian self-awareness on regional security by

\footnotetext{
${ }^{14}$ For more information about CICA's function and structure, including its meetings and secretariat, see CICA's official website, http://www.s-cica.org/page.php?page_id= $10 \&$ lang $=1$.

${ }^{15}$ Declaration of the Fourth CICA Summit on Enhancing Dialogue, Trust and Coordination for a New Asia of Peace, Stability and Cooperation, the so-called "Shanghai Declaration" outlines the main tasks the CICA is scheduled to pursue during China's chairmanship, the full text the declaration is available at http://www.cica-china.org/eng/yxxw_1/t1170133.htm.
} 
embracing, bridging and converging divergences, as well as increasing steady confidence building in multiple areas.

\section{Difficulties and Challenges for CICA Transformation}

While it is true that CICA has laid a solid foundation for its further development and transformation into a pillar of the Asian security architecture, the course of CICA's transformation and development into an OSCA will still be arduous and full of twists and turns. CICA's future development will have to face a host of difficulties and challenges, specifically in the following aspects.

First, Asia's security challenges are increasingly complicated and diverse, with more risks and uncertainties, and the dual structure in the field of security (to be further discussed below) seriously restricts effort of building up an overarching security institution.

Despite its most dynamic economic growth in the past decades, Asia's security environment is far more complicated than that of most other continents. At present, most security issues capable of exerting global repercussions have taken place in Asia, covering a plethora of traditional and nontraditional security threats, ranging from rising security dilemmas to territorial disputes and religious and sectarian conflicts, from terrorism, to nuclear nonproliferation, maritime security and drug and human trafficking, from climate change to pandemics and water resource competition. Almost all security issues are unresolvable in a short timeframe. ${ }^{16}$ This is certainly a daunting challenge to be addressed in CICA's future development.

The increasingly obvious dual structure in the field of Asian security will seriously affect CICA's future transformation and development. At present, Asian security is in a transitional period where the U.S.-led alliance system in the Asia-Pacific is facing transformation but a broader Asian security structure has not been established yet. Some countries continue to rely on the U.S. for their security, while other countries try to explore the architecture of handling security issues among Asian countries themselves. This dual structure can be macroscopically called "the United States' Asia" vs. "Asia's Asia." The former is the continuation of the United States' alliance

\footnotetext{
${ }^{16}$ See the speech by UN Secretary General Ban Ki-Moon at the Fourth CICA Summit in Shanghai, May 21, 2014, http://www.s-cica.org/page.php?page_id=710\&lang=1.
} 
system in the Cold War period, consisting mainly of Asia-Pacific countries represented by Japan, many Southeast Asian countries and Australia, while the latter mostly consists of countries in the Eurasian continent and Asia's hinterland. In a certain sense, this dual structure is the further continuation of the order of land-sea separation in the Cold War period, but with the worsening of Asia's security situation in recent years, the dual structure has been somewhat further consolidated instead of being weakened. ${ }^{17}$

An inclusive and well-represented Asian security institution needs to be built on Asian countries' common participation and concerted efforts, and no power can establish a complete security architecture in a dual or fragmented Asia. Therefore, how to cope with the complicated Asia-Pacific security situation and how to deal with the dual structure are two major difficulties that any OSCA-type organization has to face.

\section{Lack of a common}

"Asian awareness"

makes it difficult for

CICA to transform

into an overarching

security mechanism

any time soon.

Second, Asian countries still lack mutual trust and consensus on many major security issues, the shortage of a common "Asian awareness" or a common Asian identity has further complicated the prospect of establishing an overarching security mechanism in the short run governing various Asian countries' cooperation for sustainable security in the region.

Compared with the system of European countries with relatively similar cultural origin and religious origin, Asia is more of a geographical concept. In history, Asian countries never became an organic whole with strong internal driving force. ${ }^{18}$ In the Asian monsoon area east of the Pamir Plateau, the

${ }^{17}$ Huge White, The China Choice: Why America Should Share Power (Collingwood, Australia: Black Inc., 2012); Tetsuo Kotani, "Japan Allied Maritime Strategy: Balancing the Rise of Maritime China" (Washington D.C.: Center for Strategic and International Studies, April 2014), http://csis.org/files/publication/140422_Kotani_USJapanAlliance.pdf; Van Jackson, "The Rise and Persistence of Strategic Hedging across Asia: A System-Level Analysis," in Tellis et al., eds., U.S. Alliances and Partnerships at the Center of Global Power.

${ }^{18}$ As Kissinger correctly observed, “The term of 'Asia' ascribes a deceptive coherence to a disparate region. .. Until the arrival of modern Western powers, no Asian language had a word for 'Asia'... The political and economic map of Asia illustrates the region's complex tapestry," in Henry Kissinger, World Order (New York: Penguin Press, 2014), pp. 172-173. 
relatively closed hierarchical national system is dominated by Chinese Confucian culture; the dry geographical space in the west of Asia is the Muslim Middle East ruled by Islamic religious and cultural ideas; the hot South Asia is dominated by Indian civilization, while the Russian Empire with a vast geographical space exerts a profound influence on Central Asia. In such a vast geographical space where geographical environments, ethnic compositions, religious beliefs, ideologies and historical paths of development vary greatly, it is very difficult to develop recognition of the idea and status of a community among Asian countries similar to European countries. Asian countries pay more attention to security issues in their surrounding areas and sub-regional spaces and are more likely to elevate their concerns about sub-regional areas to the highest priority of their respective international strategies. In short, there is hardly any entrenched "Asian Awareness" shared by all Asian countries.

As a result, although by common sense, countries in the region should play the leading role of setting the regional security agenda and be responsible for key regional security issues, yet Asia faces two dilemmas. On the one hand, because of Asia's geographical, cultural, historical, economic, and political differences, various sub-regions in Asia, including East Asia (Southeast Asia and Northeast Asia), South Asia, Central Asia, and West Asia, have formed unique and prominent narrative features, and discussion on the issue of "whose security" in Asia tends to be divided into sub-regions' security. ${ }^{19}$ On another hand, after the Cold War, Asia's intraregional and trans-regional interactions and connections seemed to be notably enhanced. Especially after Asia became an increasingly important hub of the global industrial, transportation and value chains, Asia's economic, political, and security boundaries as a whole have seemed to become more blurred and broader. The composite effect of the above "differences," "blurredness," and "broadness" makes discussion about "whose security" in Asia more complicated. Who will represent this Asia with multiple

${ }^{19}$ For instance, the disputes and conflicts on the Korean Peninsula are still framed as a high priority security issue in Northeast Asia, while conflicts between Pakistan and India are largely regarded as a security risk in South Asia. Central Asia and Southeast Asia have also its distinguished security narratives. The so-called "Asian Security" is a kind of mosaic composed of divergent sub-regional narratives. 
differences? Who can legitimately decide the setting of the security agenda for Asia and various sub-regions? How to balance the sub-regional differences of subjects of Asia's security and the integrity of Asia as a whole?

Major countries and middle powers participating in Asia's security issues do not have consensus on regional security issues given the lack of a common identity or an Asian awareness, hindering the formation of a common security framework designed for the region. Major countries and relevant participating parties such as China, the United States, Russia, India, Japan, Turkey, Kazakhstan, and ASEAN have put forward their own strategic visions for Asia's future security issues, and have proposed the establishment of various overlapping sub-regional security mechanisms. As a Chinese senior diplomat correctly observes, "Sub-regional security cooperation has been thriving in Asia, but cooperation mechanisms are fragmented and overlapping in function." ${ }^{20}$ Complicated security mechanisms based on different purposes have sometimes resulted in complicated, fragmented, and even competitive relationships among them, which will undoubtedly exert negative influence on the establishment of the pan-Asian security and cooperation architecture.

Third, CICA still has many deficiencies and shortcomings regarding its institutional building, and the level of its development can hardly meet the requirements of the future Asian security framework.

\section{CICA must undergo}

further institutional

building before it can

become an inclusive,

comprehensive and effective pan-regional mechanism.

Promoting development of CICA into an OSCA for Asia's new security architecture will be a long and arduous course. Realizing this goal will require sufficient preparation at the level of strategic design and implementation. In view of the current state of CICA's development, its institutional building both in terms of efficacy and comprehensiveness can hardly meet the demand of regional security.

Up till now, apart from the CICA leaders' summit and the meeting of ministers of foreign affairs held once every

${ }^{20}$ Vice Minister Cheng Guoping's speech at the opening ceremony of the Meeting of CICA Senior Officials Committee, November 6, 2014, http://www.cica-china.org/eng/ yxxw_1/t1212946.htm. 
two years, ${ }^{21}$ and despite CICA's member states having in the past decade carried out multi-dimensional confidence building programs, covering economic, environment, humanitarian, military and security cooperation, CICA's influence and efficacy remain quite limited. There are mainly three reasons. First, the CBMs programs are based upon the voluntary principle where one or two CICA members take on the responsibility of coordinating for collective actions. So far there is neither a comprehensive compulsory benchmark nor an effective monitoring and implementation mechanism. The performance of CBM-implementation of each area is largely determined by the capability of the coordinating countries whose mandate from CICA is inadequate. ${ }^{22}$

Second, perhaps more importantly, for CICA's consensus and unity, discussions at the ministerial level of CICA so far have focused more on principles rather than substantive issues. Besides pace-setting speeches endorsing pre-cooked, lowest-common denominator communiqués, there are still not enough dialogues on practical outcomes which can bring about real regional delivery to regional security cooperation.

Third, the capability of the CICA Secretariat, the permanent administrative body of the conference, is yet to be fully capable of playing its due role in collaborating and facilitating the CBMs. At present, the Secretariat's capacity is not strong enough, in part because of the quality and number of professional staff working in the Secretariat, and also due to the fact that its future overarching vision of upgrading and enhancement is not yet clear. Aside from providing some basic information to member states and assisting the chairing country in organizing some meetings and daily obligations, the CICA's Secretariat's supporting function is limited compared with its counterparts in other more mature and influential international institutions, such as with regard to offering more professional and intellectual support for CBMs.

${ }^{21}$ The Chinese government has espoused some initiatives to increase the frequency of foreign ministers' meetings and even summit meetings in light of changing situations during its chairmanship. See for example, Xi Jinping's speech at the Fourth CICA Summit in Shanghai, May 21, 2014, http://www.cica-china.org/eng/yxxw_1/t1170132.htm.

${ }^{22}$ According to the author's interviews with CICA's Secretariat officials in April 2014, for the existing categories of CBMs under CICA, implementation is one of the biggest challenges as there is no mechanism of monitoring and implementation, see http://www.scica.org/page.php?page_id=11\&lang=1. 
By any means, practical implementation of confidence building measures is the route for not only taking the CICA process forward but also for retaining the relevance of the process. Until recently, CICA approach toward CBMs had been mainly declaratory. However, declared intents need to be followed up by real progress for them to remain meaningful. How and in which shape can this objective be realized depends on the collective will and mutual understanding of the member states. ${ }^{23}$

Fourth, the strong influence of major countries outside the region on Asia's security issues may also affect CICA's future transformation and development. Security analysts have long debated about how Asia's security is influenced by global events and structures, arguing that extraregional powers such as the U.S. and Russia ${ }^{24}$ often intervene in Asian regional security issues if they perceive that their own national security interests and their particular visions of global stability are threatened by such issues. ${ }^{25}$ The U.S. has been the most important extra-regional power involved in the security architecture building and agenda setting of Asia. Today, the U.S. is still leading its bilateral alliances with key economies in the region such as Japan, South Korea and Australia, while also trying to maintain the alliance system to dominate the overall regional security architecture. Since President Obama took office, Washington has begun to pursue a so-called "pivot" or "rebalancing" strategy in order to retain American leadership. The U.S. has shifted more resources and investment - diplomatic, economic and strategic ones - to the Asia-Pacific in the coming decade at the same time that the region is building up its regional security and economic architecture. ${ }^{26}$

${ }^{23}$ For basic information on the functions of the CICA Secretariat, see its official website: http://www.s-cica.org/page.php?page_id=9\&lang=1; for the review of efficacy of CBMs under CICA, see the "Evolution of CICA Process" at http://www.s-cica.org/page.php? page_id=141\&lang=1\&parent_id=133.

${ }^{24}$ Given its vast territory covering both Europe and Asia, its great influence on Central Asia, and deep involvement into continental Asian security affairs, Russia is often regarded as a Euro-Asian state. Russia itself is a full member of CICA.

${ }^{25}$ William T. Tow, ed., Security Politics in the Asia-Pacific: A Regional-Global Nexus? (Cambridge: Cambridge University Press, 2009) p. 2.

${ }^{26}$ Hillary Clinton, "America's Pacific Century," Foreign Policy, October 11, 2011, http:// foreignpolicy.com/2011/10/11/americas-pacific-century/. 
On the other hand, in the context of a dynamic balancing of power and rising uncertainties of traditional and non-traditional security challenges in Asia and the Asia-Pacific, some Asian countries are being driven to pursue hedging strategies in their approaches to foreign policies, hoping to rely on extra-regional powers, especially the United States, to enhance their own security interests, thus enhancing the United States' unique role in security affairs of Asia, especially the Asia-Pacific region. ${ }^{27}$

The goal of development of CICA as a pan-Asian security mechanism is to promote Asian countries' cooperation and dialogue, and its core is to further give play to Asian countries' key role in maintaining Asia's security and establishing the regional security framework, as well as to strengthen Asian countries' ability to solve security issues in their own region. In May 2014, President Xi Jinping encouraged Asian countries to play a leadership role in building a regional security order with the engagement of key players

The major goal of CICA is to highlight Asian countries' key role in maintaining

Asian security without precluding the constructive role of external powers. outside the region. ${ }^{28}$ Certainly, the commitment to enhance the leadership role by Asian countries, including the upgrading of CICA's status, will challenge the U.S.-led alliance system and its dominance. It has therefore caused suspicion and skepticism on the part of the U.S. and some of its key allies in the region. How these discrepancies can be reconciled and an inclusive regional security architecture worked out are factors that will greatly influence the development of Asia's regional security institutions, including CICA in the future. ${ }^{29}$

${ }^{27}$ See for example, Tellis et al., eds., U.S. Alliances and Partnerships at the Center of Global Power.

${ }^{28}$ In his speech, President Xi Jinping pointed out: "In the final analysis, it is for the people of Asia to uphold the security of Asia." For the full text of President Xi Jinping's keynote speech, visit http://www.cica-china.org/eng/zyhyhwj_ 1/yxhy/yxfh/t1170132.htm.

${ }^{29}$ Chen Dongxiao, "The Belt and Road Initiatives: China Aims to Set the Regional Cooperation Agenda," East Asian Forum, Vol. 7, No. 2 (April-June 2015), pp. 34-35. 


\section{Strategic Planning and the Road Ahead}

During the fourth summit meeting in Shanghai in 2014, Chinese President $\mathrm{Xi}$ Jinping initiated a host of proposals to enhance the capacity and institutional building of CICA. Since then, the Chinese government has stepped up its efforts to revitalize CICA by fulfilling many of its commitments made at the summit, including, among others, organizing the first annual CICA non-government forum in May 2015 in Beijing and the first Conference of the CICA Youth Council in August in Beijing. All those activities are conducive to improving CICA's social foundation and its visibility of Asia's new security concept around the world. ${ }^{30}$ However, there is still a long way to go before more substantial progress can be made regarding CICA's upgrading and transformation. From this author's perspective, the most important thing at present is to envision a clear road map for the years ahead and prioritize the main tasks so as to translate the vision into more concrete action plans.

First, at the level of macroscopic strategies, China needs to further clarify the status of CICA in the course of building Asia's security architecture, including elevating CICA's ranking in China's overall diplomatic strategies and reiterating OSCA as CICA's ultimate goal. China should make full use of its opportunity as chairing country of CICA in the next two years to formulate mid- and long-term strategic plans and propel CICA's transformation and development. Of course, China needs to garner enough support from CICA members, particularly key members such as Russia, Kazakhstan, India, Turkey, South Korea and Iran, to reach a consensus on CICA's long-term goal.

CICA's future development should be pushed forward according to key milestone goals. The overall goals of CICA's development is to develop into an important institution capable of seeking and accumulating common ground and risk-reduction in the field of regional security, become the core institution for augmenting an "Asian awareness" in the setting of regional security agenda, and ultimately lay a

\footnotetext{
${ }^{30}$ Details of these two events as well as their achievements are available at http://www. cica-china.org/chn/.
} 
solid ideational and institutional foundation for its upgrading into an OSCA in the future.

CICA's development should include three stages with milestone goals respectively for each: the period between 2014 and 2020 is the fostering stage, and the main tasks for this stage are to supplement, foster and improve capacity and institutional building, thus making CICA a formal inter-governmental organization. The period between 2020 and 2030 is the elevation stage, and the main tasks for this stage are to gradually transform and upgrade the security dialogue

A three-step approach should be adopted for the next three decades to develop CICA into a full-fledged Asian security framework. and forum into a security organization with strong operational capabilities able to directly participate in and push for solutions of Asia's security issues, as well as develop mutually complementary relationships with other regional multilateral and security cooperation institutions. The period between 2030 and 2050 is the completion stage, and the main tasks for this stage are to basically establish CICA's core position in the field of Asian security cooperation, form mutually complementary and cooperative relationships with other Asian (Asia-Pacific) sub-regional security cooperation mechanisms, and become a pillar of Asia's new security architecture.

Second, the "CICA model" of regional security cooperation should be further fostered. CICA's model should be turned into the leading model of regional security cooperation, stressing the consensus on regional security cooperation by means of "multilateral consultation on equal footing, guidance by key countries, and full consideration of small countries' opinions," strengthening and giving substance to the Asian security concept with a focus on common, comprehensive, cooperative and sustainable security.

On one hand, CICA should establish its "core brand" of regional security cooperation. CICA should take provision of public security goods with major regional influence as its important mission. In the current security context, CICA can take the issue of reconstruction of Afghanistan and maintenance of the country's lasting stability and peace as one of its key tasks. In consideration of the fact that Afghanistan's stability and peace are 
highly expected by the international community, if they are taken as CICA's core aspects of security cooperation, CICA and countries outside the region such as the United States will be provided with a new platform of cooperation and CICA's development and transformation will be promoted more smoothly.

On the other hand, CICA should strengthen its capacity and institutional building, i.e. to establish a multi-level and multi-field network to promote CICA's participation and capability in solving Asia's security issues. In particular, three areas need to be prioritized in the years ahead. First, the functions of the existing administrative bodies, especially the Secretariat, should be strengthened by having more mandates on monitoring the implementation of CBMs in addition to more stable budgets and professional staffs. Toward this end, CICA should obtain more academic backing by tapping on the regional think tanks and huge reservoir of regional experts in multiple disciplines to provide more intellectual support. Second, on the basis of fully mobilizing the Secretariat's duties, CICA should also enhance and expand the exchanges and consensus building among its members by increasing the frequency of working and expert meetings, setting up more high-level meetings, such as the meeting of defense ministers, meeting of ministers of public security, and other senior officials regarding the domestic and international security. Third, the depth and breadth of CICA's participation in Asia's security issues should be further expanded, and attention should be concentrated on bringing the CICA's role in regional security issues into full play. For instance, preparations should be made for the establishment of crisis management and emergency response mechanisms for regional risk reduction.

Third, in the course of promoting CICA's institutional building, China should take advantage of its rising influence and the activism of many middle power members of CICA to engage their indispensable cooperation and to give full scope to middle powers' vision and innovation.

As analyzed above, CICA is an international mechanism conducive to optimizing the comparative advantages of middle powers. CICA's founding state Kazakhstan and second chairing state Turkey are both typical middle powers in this region, playing an irreplaceable role in establishing CICA's basic framework and guiding principles. Many other middle and regional powers have their own visions and energy to elevate their influence in the region. Meanwhile, Asia's complicated security environment, 
CICA's broad representativeness and basic ideas of cooperation and security make it impossible for any single major country or group of major countries to fully dominate CICA's course. The elevation and development of the CICA mechanism can only be fully promoted by relying on the model of multilateral cooperation and by tapping the potential of middle powers' activism and cooperation.

Therefore, in the course of CICA's mechanism building, China should continue to deeply engage with middle and regional powers and embrace their visions, energy and influence within the CICA framework to realize their shared dream of common, comprehensive, cooperative and sustainable security.

Fourth, in the course of promoting CICA's transformation and development, the relationship between CICA and major countries outside the region, particularly the United States, should be handled appropriately.

The ultimate goal of CICA's transformation and development is to facilitate the establishment of a more open and inclusive Asian security architecture in which Asian countries themselves will be capable of playing the key role in providing the Asian region

A key element of successful CICA transformation is to encourage contribution of all members and especially to manage Sino-U.S. relations. with security public goods, thus making Asian countries themselves at the center of regional security architecture building. Here, one critical issue is how to deal with the United States' Asia-Pacific alliance system.

China, the United States, and other regional players all have hugely different perceptions on the role the American-led alliance system should play in Asian security architecture. On the one hand, one popular thought in China is that America's enhanced defense arrangements with its Asian allies have the elements of containing and tying down China. China needs to counteract the U.S.-led alliance by forming its own security coalition. Such a belief reinforces America's stereotyped perception that China intends to undermine U.S. leadership role in the regional security by weakening its alliance system. On the other hand, the U.S. reiterates that its alliance system functions as the underpinner of the Asian security order, confirming Chinese perception that the United States intends to keep China 
out of Asia's core security mechanisms. As for small and middle countries in the region, a rough balance of power between the U.S. and China is what they would like to see because such a state leaves much room for their role in building a new security order. For the benefit of an enduring Asian security order and with a view to providing more regional public goods for Asian security, the United States, China, and other regional players need to explore the possible directions in which the U.S. alliance system could evolve into a more open and inclusive arrangement; they could jointly develop a new approach to make different regional security arrangements more accommodative, less exclusive and confrontational. Whether CICA's future transformation and development can successfully address its relationship with the United States' Asia-Pacific alliance is an important issue having a direct bearing on the building of future regional security architecture. 